\title{
Mini-implants in orthodontics: a narrative review of the literature
}

\author{
Márcia Irina G. Silva1* (D), Primavera Santos Sousa1 (iD), Júlio C. M. Souza ${ }^{1,2}$ (it) \\ 'Departamento de Ciências Dentárias, CESPU - Cooperativa de Ensino Superior Politécnico Universitário, Gandra, Portugal; \\ 2Departamento de Eletrónica Industrial (CMEMS-UMinho), Universidade do Minho, Guimarães, Portugal. \\ *Autor correspondente/Corresponding author: irina.marcia@gmail.com
}

Recebido/Received: 02-09-2020; Revisto/Revised: 05-02-2021; Aceite/Accepted: 18-02-2021

\begin{abstract}
Resumo
Na Ortodontia a ancoragem sempre foi um dos maiores desafios, uma vez que fornecer um sistema de ancoragem absoluta acabou por se tornar um problema comum neste ramo. Assim, para o solucionar e uma vez que a ancoragem é um dos fatores mais importantes num tratamento ortodôntico, foram lançados dispositivos extra e intraorais. Os primeiros dispositivos lançados não foram facilmente aceites pelos pacientes e por isso, de forma a diminuir a sua cooperação durante o processo e servindo também de apoio para diversos movimentos ortodônticos considerados complexos para os sistemas tradicionais de ancoragem, começaram a ser cada vez mais utilizados mini-implantes como método de ancoragem. Os mini-implantes podem ser implantes feitos especificamente para procedimentos ortodônticos ou para a simples fixação por osteotomia. Estes destacam-se pelas suas inúmeras vantagens tais como a sua versatilidade clínica, o seu tamanho reduzido que aumenta potencialmente os locais onde podem ser inseridos, o seu baixo custo e a sua facilidade de instalação e remoção que acaba por tornar todo o processo mais simples e rápido. A força ortodôntica normalmente é aplicada imediatamente ao mini-implante ou pouco tempo após a sua instalação. $O$ sucesso destes dispositivos está no bom planeamento, na correta instalação e na orientação de higienização ao paciente, principalmente no local do mini-implante para a manutenção da saúde peri-implantar. Esta revisão bibliográfica tem como objetivo abordar a utilização dos mini-implantes na Ortodontia demonstrando como é feita a sua aplicação, os modelos existentes e a sua constituição analisando uma possível degradação e toxicidade dos seus materiais.
\end{abstract}

Palavras-chave: ancoragem ortodôntica, mini-implantes, ortodontia.

\begin{abstract}
Mini-implants appeared in Orthodontics as one of the answers to the challenges that the Absolute Anchorage Systems demanded. Several internal and external oral devices were developed, however, the first devices launched were not easily accepted by patients and it became necessary to decrease their collaboration during the process without affecting the development of a necessary solution. Mini-implants gained prominence in supporting several complex orthodontic techniques and began to be used more and more as an anchoring method due to its numerous advantages such as their clinical versatility as it can be made especially for orthodontic procedures or for simple fixation of the osteotomy. The success of these devices is in their small size that exponentially increases the places where they can be inserted, they are easy to install and remove which ends up making the process simpler, faster, and cheaper than traditional processes. Orthodontic force is applied immediately to the mini implant or shortly after its installation and the patient receives special hygiene instructions to increase the maintenance of pre-implant health. In this biographical review I will analyze the use of mini implants in Orthodontics, their application, existing models, and their constitution, also investigating the possible degradation and toxicity of their materials.
\end{abstract}

Keywords: orthodontic anchorage; mini-implants; orthodontics.

\section{INTRODUÇÃO}

Atualmente o mundo encontra-se em constante mudança e os diversos setores em desenvolvimento incluindo a medicina. Este desenvolvimento leva a que a população esteja cada vez mais exigente procurando serviços de alta qualidade que satisfaçam as suas necessidades. A medicina dentária não é exceção e encontra-se também em contínuo desenvolvimento.

\section{INTRODUCTION}

The world is constantly changing and various sectors are currently undergoing development, including medicine. This development results in an increasing demand for high-quality services to meet the needs of the population. In this case, better dental aesthetics using orthodontics is in demand (Zhang, Zhang, Bai, \& Song, 2016).

In orthodontics, one of the basic requirements of any treatment is orthodontic anchorage, which is defined as the 
Neste caso, a população exige cada vez mais uma melhor estética a nível dentário recorrendo à ortodontia (Zhang, Zhang, Bai, \& Song, 2016).

$\mathrm{Na}$ Ortodontia, um dos requisitos básicos de qualquer tratamento é a ancoragem ortodôntica, esta que é definida como a prevenção de movimentos dentários indesejados (Proffit \& Fields, 2012). Recentemente, e devido a uma maior exigência relativamente a um sistema de ancoragem que tenha a mínima colaboração do paciente, e ao mesmo tempo o máximo de eficácia possível, os dispositivos de ancoragem temporária têm mostrado ser uma excelente alternativa aos dispositivos de ancoragem tradicionais (Chen, Kyung, Zhao, \& Yu, 2009; Choi, Park, Yi, Lim, \& Hwang, 2009). Entre os diversos dispositivos temporários existentes, os mini-implantes em específico, têm sido bastante utilizados e devido às suas características como a facilidade na colocação e remoção, a possibilidade de colocação em diversos locais e a possibilidade de carga ortodôntica imediata, rapidamente se tornaram bemsucedidos (Choi, Park, Yi, Lim, \& Hwang, 2009).

Tendo em conta a crescente utilização destes dispositivos na Ortodontia, é importante perceber onde e de que forma estes devem ser instalados, para que a sua utilização seja o mais segura possível e para que haja sucesso no tratamento ortodôntico sem que seja posta em causa a viabilidade do mesmo ou a segurança do paciente. Os mini-implantes são assim considerados um sistema de ancoragem fiável e, por se ancorarem no osso esquelético providenciam uma ancoragem absoluta com apenas um simples procedimento cirúrgico (Lemieux et al., 2011). Graças aos seus fatores inovadores, os mini-implantes estão a transformar o planeamento ortodôntico e a própria biomecânica.

Esta revisão bibliográfica tem como objetivo analisar a utilização de mini-implantes em ortodontia, tendo em conta a sua aplicação, os modelos existentes e por fim o seu material de fabricação e os possíveis efeitos do mesmo.

\section{MÉTODOS}

Para a elaboração desta revisão, foi feita uma pesquisa bibliográfica baseada em artigos científicos, revistas científicas e livros. Estes surgiram através de diferentes bases de dados, tais como: Science Direct, Google Scholar, Scielo.

\section{APLICAÇÃO DE MINI-IMPLANTES}

Para que a utilização de mini-implantes como ancoragem absoluta seja bem-sucedida, é importante que haja um planeamento adequado e individualizado. O ortodontista, após definir o plano de tratamento adequado, deverá definir o tipo de movimento desejado, a quantidade de mini-implantes necessária, e os locais adequados para a sua inserção (Villela, Villela, Bezerra, Labiossière Júnio, \& Soares, 2004). Após um diagnóstico e planeamento adequados, deverá definir-se também o tipo de ancoragem pretendida. Esta pode ser classificada como direta em que a carga é aplicada diretamente no mini-implante ou indireta em que o mini-implante é utilizado para a imobilização de um dente, ou grupo de dentes, e a força é aplicada sobre estes (Favero, Brollo, \& Bressan, 2002).

Assim, resumindo o modo como os mini-implantes são instalados, e de maneira a uniformizar esta instalação, prevention of unwanted tooth movement (Proffit \& Fields, 2012). Recently, there has been a greater demand for an anchorage system that has minimal patient collaboration but is also as effective as possible; thus, temporary anchorage devices have been indicated as an excellent alternative to traditional anchorage devices (Chen, Kyung, Zhao, \& Yu, 2009; Choi, Park, Yi, Lim, \& Hwang, 2009). Among the various existing temporary devices, mini-implants in particular have been widely used, and due to their characteristics, such as their ease of placement and removal, the possibility of placement in different areas and the possibility of immediate orthodontic loading, mini-implants quickly became very successful (Choi, Park, Yi, Lim, \& Hwang, 2009). Considering the growing use of these devices in orthodontics, it is important to understand where and how they should be installed to ensure that their use is as safe as possible and for orthodontic treatment to be successful without jeopardizing the viability or safety of the patient. Mini-implants are thus considered a reliable anchorage system, and as they are anchored in skeletal bone, they provide absolute anchorage with just a simple surgical procedure (Lemieux et al., 2011). Thanks to their innovative factors, mini-implants are transforming orthodontic planning and biomechanics itself.

This literature review aims to analyse the use of mini-implants in orthodontics, taking into account their application and the existing models as well as the fabrication material and its possible effects.

\section{METHODS}

To conduct this review, bibliographic research was carried out based on scientific articles, scientific journals and books. These were found through different databases, such as Science Direct, Google Scholar, and Scielo.

\section{MINI-IMPLANT APPLICATIONS}

For the success of mini-implants acting as absolute anchorages, it is important that adequate and individualized planning occurs. The orthodontist, after defining the appropriate treatment plan, must define the desired type of movement, the number of mini-implants needed, and the appropriate locations for their insertion (Villela, Villela, Bezerra, Labiossière Júnio, \& Soares, 2004). After proper diagnosis and planning is conducted, the type of anchorage required must also be defined. This anchorage can be classified as direct, in which the load is applied directly to the mini-implant, or indirect, in which the mini-implant is used to immobilize a tooth or group of teeth, and the force is applied to the teeth (Favero, Brollo, \& Bressan, 2002).

Thus, to summarize how mini-implants are installed and to standardize their installation, minimizing errors and maximizing the chances of success, the following protocol is suggested (Marassi, Marassi, \& Cozer, 2016):

I. Perform prophylaxis and superficial anaesthesia at the installation site.

II. The mesiodistal position should be defined according to interproximal radiography, the clinical evaluation of the alveolar process, the dental position and the type of movement that was performed. The vertical position should be marked using a measure of $4 \mathrm{~mm}$ more than the depth of the gingival sulcus as the occlusal limit of installation. It is necessary to increase the depth from 2 
minimizando erros e maximizando as hipóteses de sucesso, é sugerido o seguinte protocolo (Marassi, Marassi, \& Cozer, 2016):

I. Executar profilaxia e anestesia superficial no local de instalação.

II. Definir o posicionamento mesiodistal, de acordo com a radiografia interproximal, a avaliação clínica do processo alveolar, o posicionamento dentário e o tipo de movimento que será executado. Marcar o posicionamento vertical utilizando-se como limite oclusal de instalação a medida de $4 \mathrm{~mm}$ a mais que a profundidade do sulco gengival. É necessário aumentar de 2 a $4 \mathrm{~mm}$ para determinar este limite mínimo em caso de intrusão.

III. Medir a espessura da mucosa com uma sonda milimetrada para definir a extensão do transmucoso do mini-implante que será utilizado.

IV. Instalação sem perfuração prévia: marcação do ponto de inserção através de uma pequena edentação na cortical óssea obtida aplicando-se o mini-implante perpendicular à cortical óssea para evitar o deslize do mini-implante nas instalações anguladas. Após este passo, é feita a perfuração da cortical com o miniimplante angulado em torno de 45 a $60^{\circ}$ em relação ao processo alveolar.

V. Instalação com perfuração prévia: em áreas de densidade óssea maior (em geral, na região posterior de mandíbula e sutura palatina), deve perfurar-se a cortical utilizando uma chave manual ou digital com fresa lança ou o contra-ângulo de redução com fresa helicoidal em cerca de 300 rpm sob irrigação de soro fisiológico gelado.

VI. Instalar o mini-implante angulado, acompanhando a angulação da perfuração da cortical, exercendo pressão axial sobre a chave com o centro da mão e girando a chave com a ponta dos dedos até $2 / 3$ da inserção do mini-implante. Após $2 / 3$ da instalação, recomenda-se conferir a angulação horizontal e a vertical e prosseguir com a instalação sem exercer força axial, utilizando apenas movimentos giratórios com a ponta dos dedos.

VII. Fim da instalação: conferir se foi obtida a estabilidade primária do mini-implante, ou seja, ausência de mobilidade e, caso não haja, deverá ser utilizado um mini-implante com diâmetro maior ou deverá ser escolhido outro sítio para aplicação do mini-implante. Recomenda-se que seja feita uma radiografia de controlo para confirmar a ausência de contato entre o mini-implante e raízes ou estruturas nobres. Devem ser fornecidas instruções pós-operatórias ao paciente, orientando-o para que evite exercer pressão sobre o mini-implante com a língua, dedo ou qualquer objeto, bem como a definição de regras para uma ótima higienização no local da instalação através de escovação e controlo químico do biofilme com colutórios. Recomenda-se ainda que o paciente ingira um analgésico, 3 horas após a instalação, a fim de evitar sensibilidade pós-operatória. to $4 \mathrm{~mm}$ to determine this minimum limit in the case of intrusion.

III. Measure the mucosal thickness with a millimetre probe to define the transmucosal extension of the mini-implant that will be used.

IV. Installation without previous perforation: mark the insertion point through a small indentation in the bone cortex that is obtained by applying the mini-implant perpendicular to the bone cortex to prevent the miniimplant from slipping in angled installations. After this step, the cortex should be perforated with the miniimplant at an angle of approximately 45 to $60^{\circ}$ in relation to the alveolar process.

V. Installation with previous drilling: in areas of greater bone density (generally in the posterior region of the mandible and palate suture), the cortical bone must be drilled using a manual or digital wrench with a spear cutter or the reduction contra-angle with a helical cutter at approximately $300 \mathrm{rpm}$ under irrigation with ice-cold saline.

VI. Install the angled mini-implant following the angulation of the cortical perforation by exerting axial pressure on the wrench with the centre of your hand and turning the wrench with your fingertips up to $2 / 3^{\text {rd }}$ of the mini-implant insertion. After $2 / 3^{\text {rd }}$ of the installation is complete, it is recommended to check the horizontal and vertical angulation and proceed with the installation without exerting axial force, using only rotating movements with your fingertips.

VII. End of installation: check if the primary stability of the mini-implant has been achieved, specifically, if there is a lack of mobility. If not, a larger diameter mini-implant should be used or another site should be chosen for the mini-implant application. It is recommended that a control radiograph should be taken to confirm the absence of contact between the mini-implant and noble roots or structures. Postoperative instructions must be provided to the patient, which should advise him or her to avoid exerting pressure on the mini-implant with his tongue, finger or any object, as well as to define the recommendations for optimal hygiene at the installation site via brushing and mouthwash to chemically control biofilm formation. It is also recommended that the patient ingests an analgesic 3 hours after installation to avoid postoperative sensitivity.

\section{MINI-IMPLANT MODELS}

Mini-implants can be classified according to where they are inserted or the insertion technique that is used.

Thus, depending on where they are placed, mini-implants can be classified as the following (Santos \& Silveira, 2019):

- Interradicular: if placed in the alveolar process, between the tooth roots or close to the roots.

- Extraradicular: if placed outside the alveolar process that supports the roots.

- According to the insertion technique, miniimplants can be self-drilling and self-tapping (Fig. 1) 


\section{MODELOS DE MINI-IMPLANTES}

Os mini-implantes podem ser classificados de acordo com o local onde são inseridos ou a técnica de inserção que é utilizada.

Assim, consoante o local da sua colocação, os miniimplantes podem ser (Santos \& Silveira, 2019):

- Interradiculares: se forem colocados no processo alveolar, entre as raízes dentárias ou próximo delas.

- Extraradiculares: caso sejam colocados fora do processo alveolar que suporta as raízes.

- De acordo com a técnica de inserção, os mini-implantes podem ser auto-perfurantes e auto-rosqueantes (Fig.1) (Baumgaertel, Razavi, \& Hans, 2008).

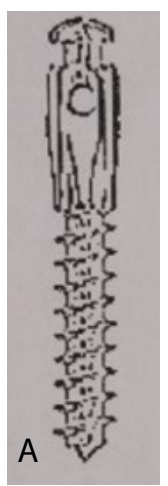

Figura/Figure 1: Mini implantes auto-perfurante/Self-drilling mini implants (A). Mini implante autorosqueantes/Self-tapping mini implant (B).

Os sistemas de mini-implantes auto-perfurantes têm uma ponta cortante, ou seja, possuem um sistema de perfuração automática, podendo ser necessárias forças elevadas para a perfuração do osso cortical. Este processo apresenta algumas desvantagens, por exemplo, o desconforto do paciente e reabsorção que consequentemente conduzirá à falha do miniimplante devido a uma maior compressão do osso. Para além disso, através da aplicação de uma força excessiva, pode existir um desvio do trajeto do dispositivo (Baumgaertel, Razavi, \& Hans, 2008; Lee \& Baek, 2010). Contudo, este sistema apresenta uma melhor estabilidade primária em comparação com o auto-rosqueante e o facto de não serem utilizadas brocas no processo acaba por ter vantagens psicológicas para o paciente (Baumgaertel, Razavi, \& Hans, 2008; Wilmes, Rademacher, Olthoff, \& Drescher, 2006).

Por outro lado, os sistemas de mini-implantes autorosqueantes têm uma ponta não cortante e, por este motivo, necessitam de um buraco piloto do mesmo comprimento que o mini-implante antes da sua inserção (Tepedino, Masedu, \& Chimenti, 2017; Baumgaertel, Razavi, \& Hans, 2008). Após a perfuração do buraco piloto, os mini-implantes autorosqueantes são colocados sem qualquer dificuldade e com o mínimo de danos nos tecidos, não permitindo a ocorrência de desvios (Baumgaertel, Razavi, \& Hans, 2008). Geralmente, estes são considerados sistemas ligeiramente mais invasivos, apesar de apresentarem vantagens na perfuração do osso cortical.

\section{MATERIAIS PARA FABRICAÇÃO DE MINI-IMPLANTES}

Na fabricação dos vários tipos de implantes comercialmente
(Baumgaertel, Razavi, \& Hans, 2008).

Self-drilling mini-implant systems have a cutting tip, that is, they have an automatic perforation system, and high forces may be required to perforate the cortical bone. This process has some disadvantages, for example, patient discomfort and resorption which will consequently lead to mini-implant failure due to greater bone compression. Furthermore, through the application of excessive force, the device path may deviate (Baumgaertel, Razavi, \& Hans, 2008; Lee \& Baek, 2010). However, this system has better primary stability compared to self-tapping and the fact that no drills are used in the process ends up having psychological advantages for the patient (Baumgaertel, Razavi, \& Hans, 2008; Wilmes, Rademacher, Olthoff, \& Drescher, 2006).

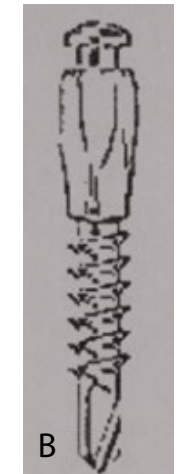

On the other hand, self-tapping mini-implant systems have a noncutting tip and, for this reason, the systems require a pilot hole with the same length as the mini-implant prior to insertion (Tepedino, Masedu, \& Chimenti, 2017; Baumgaertel, Razavi, \& Hans, 2008). After drilling the pilot hole, self-tapping mini-implants are placed without any difficulty and with minimal tissue damage, which prevents deviations from occurring (Baumgaertel, Razavi, \& Hans, 2008). These systems are generally considered to be slightly more invasive, although they have advantages in cortical bone perforation.

\section{MATERIALS FOR MANUFACTURING MINI-IMPLANTS}

Different materials are used to manufacture the various types of commercially available implants. However, regardless of the material, implants must be nontoxic, biocompatible, have favourable mechanical properties and be able to resist stress, deformation and corrosion (Favero, Brollo, \& Bressan, 2002; Huang, Shotwell, \&Wang, 2005).

There are several materials that have high biocompatibility, including materials commonly used in the manufacture of implants, which can be divided into the following groups: biotolerant (stainless steel and chromium-cobalt alloys), bioinert (titanium and carbon) and bioactive (hydroxyapatite and calcium phosphate) (Favero, Brollo, \& Bressan, 2002; Huang, Shotwell, \& Wang, 2005). Among all these materials, titanium is the most commonly used implant material in orthodontics (Mabilleau et al., 2006; Egeni, Moschini, Jaksic, \& Passi, 1996) due to its excellent resistance to corrosion in body fluids, its proven biocompatibility in human tissues and its adequate mechanical properties, such as 
disponíveis são utilizados diferentes materiais. No entanto, seja qual for o material, este deve ser atóxico, biocompatível, ter propriedades mecânicas favoráveis e ser capaz de resistir à tensão, deformação e corrosão (Favero, Brollo, \& Bressan, 2002; Huang, Shotwell, \& Wang, 2005).

Existem vários materiais que possuem alta biocompatibilidade, entre eles estão os materiais comumente utilizados na fabricação de implantes, os quais podem ser divididos em três grupos: os biotolerantes (aço inoxidável e ligas cromo-cobalto), os bioinertes (titânio e carbono) e os bioativos (hidroxiapatita e fosfato de cálcio) (Favero, Brollo, \& Bressan, 2002; Huang, Shotwell, \& Wang, 2005). Entre todos estes materiais, o titânio é o mais utilizado nos implantes em ortodontia (Mabilleau et al., 2006; Egeni, Moschini, Jaksic, \& Passi, 1996) devido à sua excelente resistência à corrosão nos fluidos corporais, à sua biocompatibilidade comprovada em tecidos humanos e às suas propriedades mecânicas adequadas, como alta tenacidade (Mabilleau et al., 2006).

A desvantagem do uso do titânio na fabricação de miniimplantes para ancoragem ortodôntica é que estes dispositivos apesar de terem dimensões reduzidas precisam de suportar forças ortodônticas de alta magnitude, havendo a possibilidade de fratura durante os procedimentos de inserção e/ou remoção. Assim, de forma a contornar este risco, as propriedades mecânicas do Titânio Comercial Puro ( $\mathrm{Ti} \mathrm{CP}$ ) podem ser melhoradas pela adição de elementos de liga. Estas ligas de titânio, por possuírem características bioativas inferiores ao titânio puro, proporcionam uma resistência mecânica maior, com facilidade de remoção no final do tratamento, pois garantem um grau de osteointegração baixo. (Niinomi, 1998).

Atualmente, os mini-implantes ortodônticos são produzidos com uma Liga de titânio grau $\mathrm{V}$ (Ti-6Al-4V), que os tornam mais resistentes à fratura e menos bioativos do que os mini-implates anteriormente utilizados. Estes apresentam dimensões entre 1,2 e $2 \mathrm{~mm}$ de diâmetro com 6 a $12 \mathrm{~mm}$ de comprimento, e são selecionados de acordo com o local de instalação e a aplicação clínica planeada (Niinomi, 1998). high tenacity (Mabilleau et al., 2006).

The disadvantage of using titanium to manufacture miniimplants for orthodontic anchorage is that these devices, despite having reduced dimensions, need to support orthodontic forces of high magnitudes, and there is a possibility of fracture during the insertion and/or removal procedures. Thus, to circumvent this risk, the mechanical properties of pure commercial titanium ( $\mathrm{Ti} \mathrm{CP}$ ) can be improved by adding alloying elements. These titanium alloys, as they have bioactive characteristics inferior to pure titanium, provide greater mechanical resistance, are easy to remove at the end of the treatment, and they guarantee a low degree of osseointegration. (Niinomi, 1998).

Currently, orthodontic mini-implants are produced with a grade $\mathrm{V}$ titanium alloy (Ti-6Al-4 V), which makes them more resistant to fracture and less bioactive than the previously used mini-implants. These titanium implants have dimensions between 1.2 and $2 \mathrm{~mm}$ in diameter and 6 to $12 \mathrm{~mm}$ in length and are selected according to the installation site and planned clinical application (Niinomi, 1998).

\section{DEGRADATION AND TOXICITY OF MINI-IMPLANTS}

The deterioration of a material by environmental chemical or electrochemical action, which can be associated or not associated with mechanical efforts, is called corrosion. This deterioration represents unwanted harmful changes such as wear, chemical variations or structural changes that happen spontaneously and constantly transform metallic materials. These materials thus experience altered durability and performance and can no longer achieve their intended purposes (Gentil, 2007).

Corrosion problems are common and occur in various industries, such as the chemical, oil, naval, civil construction, automobile, railway, maritime, road, dental and medicine industries (Gentil, 2007). Dentistry uses different metallic materials in the form of restorations, dental prostheses, dental implants, and orthodontic appliances, among others. One of the fundamental conditions is that the metallic materials resist corrosion caused by saliva and food, which can be alkaline or acidic.

Tabela/Table 1: Algumas ligas de titânio e uma de aço mais utilizadas com informação da marca comercial e fabricante/Some commonly used titanium and steel alloys with trademark and manufacturer information.

\begin{tabular}{|c|c|c|}
\hline Marca Comercial/Brand Name & Fabricante/Manufacturer & Composição da liga/Alloy Composition \\
\hline $\begin{array}{l}\text { Infinitas Mini } \\
\text { Implant }\end{array}$ & Dentsply Gac & $\begin{array}{c}\text { Ti grade 23- } \\
\text { Ti } 6 \text { Al 4V }\end{array}$ \\
\hline $\begin{array}{l}\text { Aarhus Mini } \\
\text { Implante }\end{array}$ & Medicon & $\begin{array}{c}\text { Ti grade 23- } \\
\text { Ti } 6 \text { Al 4V }\end{array}$ \\
\hline VectorTas & Ormco & $\begin{array}{l}\text { Ti grade 23- } \\
\text { Ti } 6 \text { Al 4V }\end{array}$ \\
\hline Unitek TADs & $3 \mathrm{M}$ & $\begin{array}{l}\text { Ti grade 23- } \\
\text { Ti } 6 \text { Al } 4 \text { V Eli }\end{array}$ \\
\hline Leone TADs & Leone & $\begin{array}{c}\text { Stainless } \\
\text { steel-316 L }\end{array}$ \\
\hline
\end{tabular}

\section{DEGRADAÇÃO E TOXICIDADE DE MINI-IMPLANTES}

À deterioração de um material por ação química ou eletroquímica do meio ambiente, associada ou não a esforços mecânicos é dado o nome de corrosão. Esta deterioração representa alterações prejudiciais indesejáveis como o desgaste,
Titanium is the material used the most in orthodontics. When the surface of this material contacts air or an aqueous medium, it forms a thin layer of titanium oxide, which is approximately 2 to $6 \mathrm{~nm}$ thick, as a result of its interaction with oxygen (Mabilleau et al., 2006). The contact between the implant 
variações químicas ou modificações estruturais que acontecem de forma espontânea e transformam constantemente os materiais metálicos. Estes, por sua vez, têm a sua durabilidade e desempenho alterados, deixando de satisfazer os fins a que se destinam (Gentil, 2007).

Os problemas de corrosão são frequentes e ocorrem nas mais variadas atividades como, por exemplo, nas indústrias química, petrolífera, naval, de construção civil, automobilística, ferroviário, marítimo, rodoviários, na medicina dentária e na medicina (Gentil, 2007). A medicina dentária utiliza diferentes materiais metálicos sob a forma de restaurações, próteses dentárias, implantes dentários, aparelhos ortodônticos, entre outros. Uma das condições fundamentais é que estes resistam à corrosão da saliva e de alimentos, que podem ser alcalinos ou ácidos.

O titânio é o material mais utilizado na ortodontia. Quando a superfície deste material entra em contato com o ar, ou com um meio aquoso, forma uma fina camada de óxido de titânio, de aproximadamente 2 a $6 \mathrm{~nm}$ de espessura como resultado da sua interação com o oxigênio (Mabilleau et al., 2006). O contato entre o implante e o tecido receptor é feito por esta camada, que se forma na superfície do implante, a qual permite o processo de osseointegração (Al-Mayouf, Al-Mobarak, Al-Swayih, \& Al-Jabab, 2004). Assim, a biocompatibilidade do titânio é em grande parte atribuída à formação da camada de óxido na sua superfície (Zaffe, Bertoldi, \& Consolo, 2003). A resistência à corrosão desta material está então relacionada com a resistência à dissolução do óxido de proteção que se forma na sua superfície. Quanto maior a resistência à degradação do óxido superficial, melhor será a resistência à corrosão do material.

Como referido anteriormente, atualmente os miniimplantes ortodônticos são produzidos com uma liga de titânio grau $V$, esta possui uma maior resistência mecânica e por isso é utilizada na fabricação de implantes que devem suportar cargas (Johansson, Han, Wennerberg, \& Albrektsson, 1998). No entanto, devido à baixa resistência da liga de titânio aos fluidos corporais (Tian, Chen, Li, \& Huo, 2005) pode levar à corrosão do mini-implante (Zaffe, Bertoldi, \& Consolo, 2003).

Quando os implantes são colocados permanentemente no osso, é importante ter em consideração a biocompatibilidade pois, mesmo com os materiais mais inertes, algum grau de corrosão e dissolução metálica é inevitável. No entanto, e uma vez que os mini-implantes de ancoragem ortodôntica são removidos após a sua utilização no tratamento ortodôntico, este acaba por não ser um problema relevante (Roberts, Smith, Zilberman, Mozsary, \& Smith, 1984).

\section{CONCLUSÕES}

De forma a facilitar o tratamento de casos mais complexos de má-oclusão surgiram na ortodontia os mini-implantes, que acabaram por se tornar uma mais-valia para na área.

Entre as inúmeras vantagens na utilização de miniimplantes é possível destacar o seu tamanho reduzido, a facilidade de colocação, a possibilidade de serem sujeitos a carga imediata sem esperar meses pela cicatrização, o conforto para o paciente, o rácio custo benefício e o facto de proporcionarem uma ancoragem absoluta, algo fundamental num tratamento ortodôntico. Relativamente às suas desvantagens, apesar de and the recipient tissue is made by this layer, which forms on the surface of the implant and allows the osseointegration process to occur (Al-Mayouf, Al-Mobarak, Al-Swayih, \& Al-Jabab, 2004). Thus, the biocompatibility of titanium is largely attributed to the formation of the oxide layer on its surface (Zaffe, Bertoldi, \& Consolo, 2003). The corrosion resistance of this material is thus related to its resistance to the dissolution of the protective oxide that forms on its surface. The greater the resistance to surface oxide degradation is, the better the corrosion resistance of the material.

As previously mentioned, orthodontic mini-implants are currently produced with a grade $V$ titanium alloy, which has greater mechanical strength than that of other alloys and is therefore used in the manufacture of load-supporting implants (Johansson, Han, Wennerberg, \& Albrektsson, 1998). However, due to the low resistance of the titanium alloy to body fluids (Tian, Chen, Li, \& Huo, 2005), the use of titanium alloys can lead to mini-implant corrosion (Zaffe, Bertoldi, \& Consolo, 2003).

When implants are permanently placed in bone, it is important to consider biocompatibility even with the most inert materials as some degree of corrosion and metallic dissolution is inevitable. However, since orthodontic anchorage miniimplants are removed after their use in orthodontic treatment, this is not a relevant problem (Roberts, Smith, Zilberman, Mozsary, \& Smith, 1984).

\section{CONCLUSIONS}

To facilitate the treatment of more complex cases of malocclusion, mini-implants have emerged in orthodontics and have since becoming an asset in the area.

Among the numerous advantages of using mini-implants, the highlights include their reduced size, ease of placement, possibility of being subjected to immediate loading without waiting months for healing, patient comfort, cost-benefit ratio and ability to provide absolute anchorage, which is essential in orthodontic treatment. Regarding the disadvantages of miniimplants, although unlikely, there is a possibility of trauma to the soft tissues, periodontal ligament or dental roots, damage to adjacent structures, inflammation of the peri-implant tissues and fracture of the mini-implant itself.

An advantage in using mini-implants is their stability when subjected to orthodontic loads during treatment. This stability depends on bone density, the state of type and thickness of the peri-implant soft tissues, the surgical technique of the design and the load exerted. In addition, to ensure the desired tooth movement, it is essential to properly control the vectors when using mini-implants.

In general, mini-implants have been shown to be a very efficient method for anchoring to perform various orthodontic mechanics. The use of mini-implants as an anchorage for orthodontic movement is a very useful resource and requires very little patient collaboration. For the success of these devices, it is essential to follow the correct planning procedures and correct application.

\section{AUTHORSHIP CONTRIBUTIONS}

Methodology: Irina Silva, Júlio Souza; Validation: Irina Silva, Júlio Souza, Primavera Santos; Formal analysis: Júlio Souza, 
serem improváveis, é possível referir a possibilidade de trauma dos tecidos moles, do ligamento periodontal ou das raízes dentárias, danos nas estruturas adjacentes, inflamação dos tecidos peri-implantares e fratura do próprio mini-implante.

Uma mais valia na utilização dos mini-implantes é a sua estabilidade quando sujeitos a cargas ortodônticas durante o tratamento. Esta estabilidade depende da densidade óssea, do estado tipo e espessura dos tecidos moles peri-implantares, da técnica cirúrgica do design e da carga exercida. Para além disso, para assegurar os movimentos dentários pretendidos é fundamental o controlo adequado dos vetores na utilização de mini-implantes.

De uma forma geral, os mini-implantes têm-se mostrado um método bastante eficiente na ancoragem para a realização de diversas mecânicas ortodônticas. A sua utilização como ancoragem para movimentação ortodôntica é um recurso muito útil e praticamente dispensa a colaboração do paciente. Para o sucesso destes dispositivos é essencial que seja seguida a correta indicação do planeamento e correta aplicação.

\section{CONTRIBUIÇÕES AUTORAIS}

Metodologia: Irina Silva, Júlio Souza; Validação: Irina Silva, Júlio Souza, Primavera Santos; Análise formal: Júlio Souza, Primavera Sousa; Investigação: Irina Silva; Recursos: Irina Silva; Curadoria de dados: Irina Silva; Redação - preparação do draft original: Irina Silva; Redação - revisão e edição: Irina Silva, Júlio Souza, Primavera Sousa; Visualização: Irina Silva, Júlio Souza, Primavera Sousa; Supervisão: Júlio Souza, Primavera Sousa; Coordenação do projeto: Júlio Souza, Primavera Sousa.

\section{REFERÊNCIAS BIBLIOGRÁFICAS/REFERENCES}

Al-Mayouf, A., Al-Mobarak, N., Al-Swayih, A. A., \& Al-Jabab, A. S., Corrosion behavior of a new titanium alloy for dental implant applications in fluoride media. Mater Chem Phys 86(2-3), 320-329, 2004.

Baumgaertel , S., Razavi, M. R., \& Hans, M. G., Mini-implant anchorage for the orthodontic practitioner. Am J Orthod Dentofacial Orthop 133(4), 621-627, 2008.

Chen, Y., Kyung, H. M., Zhao, W. T., \& Yu, W. J., Critical factors for the success of orthodontic mini-implants: A systematic review. Am J Orthod Dentofacial Orthop 135(3), 284-291, 2009.

Choi, J., Park, C., Yi, S., Lim, H., \& Hwang, H., Bone density measurement in interdental areas with simulated placement of orthodontic miniscrew implants. Am J Orthod Dentofacial Orthop 136(6), 766-767, 2009.

Egeni, G., Moschini, G., Jaksic, M., \& Passi, P. PIXE and micro-PIXE studies of ion release around endosseous implants in animals. Nucl. Instrum. Methods Phys. Res., B 109, 289-293, 1996.

Favero, L., Brollo, P., \& Bressan, E., Orthodontic anchorage with specific fixtures: related study analysis. Am J Orthod Dentofacial Orthop 122(1), 84-94, 2002.

Gentil, V. (2007). Corrosão: $5^{\mathrm{a}}$ ed. Rio de Janeiro: LTC Editora.

Huang, L., Shotwell , J., \& Wang, H., Dental implants for orthodontic anchorage. Am J Orthod Dentofacial Orthop 127(6), 13-22, 2005

Johansson, C., Han, C., Wennerberg, A., \& Albrektsson, T., A quantitative comparison of machined commercially pure titanium and titanium-aluminum-vanadium implants in rabbit bone. Int J Oral Maxillofac Implants 13(3), 315-321, 1998.

Lee, N. K., \& Baek, S. H., Effects of the diameter and shape of orthodontic mini-implants on microdamage to the cortical bone.
Primavera Sousa; Research: Irina Silva; Resources: Irina Silva; Data curation: Irina Silva; Writing - preparation of original draft: Irina Silva; Writing - proofreading and editing: Irina Silva, Júlio Souza, Primavera Sousa; Visualization: Irina Silva, Júlio Souza, Primavera Sousa; Supervision: Júlio Souza, Primavera Sousa; Project coordination: Júlio Souza, Primavera Sousa. 


\section{Artigo de Revisão | Review Article}

Am J Orthod Dentofacial Orthop 138(1), 1-8, 2010.

Lemieux, G., Hart, A., Cheretakis, C., Goodmurphy, C., Trexler, S., McGary, C., \& Retrouvey, J., Computed tomographic characterization of mini-implant placement pattern and maximum anchorage force in human cadavers. Am J Orthod Dentofacial Orthop 140(3), 356-365, 2011.

Mabilleau, G., Bourdon, S., Joly-Guillou, M., Filmon, R., Baslé, M., \& .Chappard, D., Influence of fluoride, hydrogen peroxide and lactic acid on the corrosion resistance of commercially pure titanium. Acta Biomater 2(1), 121-129, 2006.

Marassi, C., Marassi, C., \& Cozer, T. B. (2016). Miniimplantes Ortodônticos. Em Ortodontia e Ortopedia Funcional dos Maxilares (pp. 199-206).

Niinomi, M., Mechanical properties of biomedical titanium alloys. Mater Sci Eng A 243(1-2), 231-236, 1998.

Proffit, W., \& Fields, H. (2012). Contemporary Orthodontics 5th Edition. St.Louis: Mosby.

Roberts, W., Smith, R., Zilberman, Y., Mozsary, P., \& Smith, R., Osseous adaptation to continuous loading of rigid endosseous implants. Am J Orthod 86(2), 95-111, 1984.

Santos, M. E., \& Silveira , C. A., Mini-implantes interradiculares e mini-implantes extra-alveolares na movimentação ortodôntica. Revista Cientifica FUNVIC 4(2), 31-38, 2019.

Tepedino, M., Masedu, F., \& Chimenti, C., Comparative evaluation of insertion torque and mechanical stability for self-tapping and self-drilling orthodontic miniscrews - an in vitro study. Head Face Med 13(1), 10, 2017.

Tian, Y. S., Chen, C. Z., Li, S. T., \& Huo, Q. H., Research progress on laser surface modification of titanium alloys. Appl Surf Sci 242(12), 177-184, 2005.

Villela, H., Villela , P., Bezerra, F., Labiossière Júnio, M. A., \& Soares, A. P., Utilização de mini-implantes para anco-ragem ortodôntica direta. Innovation Journal 8(1), 5-12, 2004.

Wilmes, B., Rademacher , C., Olthoff , G., \& Drescher, D., Parameters affecting primary stability of orthodontic miniimplants. J Orofac Orthop 67(3), 162-174, 2006.

Zaffe, D., Bertoldi, C., \& Consolo , U., Element release from titanium devices used in oral and maxillofacial surgery. Biomaterials 24(6), 1093-1099, 2003.

Zhang, R., Zhang, W., Bai, X., \& Song, X., Application and Curative Effect of Micro-implant Anchorage in Orthodontics. Trop J Pharm Res (1), 651-655, 2016. 